\title{
PENGARUH FAKTOR FUNDAMENTAL PERUSAHAAN TERHADAP RETURN SAHAM SEKTOR KEUANGAN SYARIAH YANG TERDAFTAR DALAM DAFTAR EFEK SYARIAH TAHUN 2015-2017
}

\author{
Kusnadi \\ Universitas Terbuka \\ Sufyati HS \\ Universitas Nasional \\ Ginta Ginting \\ Universitas Terbuka \\ Email: nh4edy@yahoo.com
}

\begin{abstract}
This study aims to analyze the influence of corporate fundamental factors such as ROA (Return on Assets), ROE (Return On Equity), EPS (Earning per Share), NPM (Net Profit Margin), DER (Dept to Equity Ratio) and CR (Current Ratio) of financial sector stock returns listed in the Daftar Efek Syariah (DES). The sample of this study were determined using the saturated sampling method in which all populations were sampled. The research sample consisted of 5 companies with an observation period of 2015-2017 to obtain 15 observational data. Data analysis used multiple linear regression analysis. The results showed that ROA, ROE, EPS, NPM, DER and CR together had a positive and significant effect on stock returns. While partially ROA, ROE, NPM, and CR have no significant effect on stock returns. Only EPS and DER have a positive and significant effect on stock returns. While the most dominant variable influencing stock returns is DER. The theoretical implication of this research was that investors need to consider EPS and DER by looking at the ups and downs of the ratio. Practically, in determining investor stock returns, do not only pay attention to the company's internal factors, but must pay attention to the company's external factors.
\end{abstract}

Keywords: Fundamental Factors, ROA, ROE, EPS, NPM, DER, CR, Stock Return.

Abstrak 
Penelitian ini bertujuan menganalisis pengaruh faktor fundamental perusahaan berupa ROA (Return on Assets), ROE (Return On Equity), EPS (Earning per Share), NPM (Net Profit Margin), DER (Dept to Equity Ratio) dan CR (Current Ratio) terhadap return saham sektor keuangan yang terdaftar dalam Daftar Efek Syariah (DES). Sampel penelitian ini ditentukan menggunakan metode sampling jenuh yaitu semua populasi menjadi sampel. Sampel penelitian terdiri dari 5 perusahaan dengan periode pengamatan tahun 2015-2017 sehingga diperoleh 15 data pengamatan. Analisis data menggunakan analisis regresi linier berganda. Hasil penelitian menunjukkan bahwa ROA, ROE, EPS, NPM, DER dan CR secara bersama-sama berpengaruh positif dan signifikan terhadap Return Saham. Sedangkan secara parsial ROA, ROE, NPM, dan CR tidak berpengaruh signifikan terhadap Return Saham. Hanya EPS dan DER yang berpengaruh positif dan signifikan terhadap Return Saham. Sedangkan variabel paling dominan berpengaruh terhadap Return Saham adalah DER. Implikasi teoritis dari penelitian ini adalah bahwa investor perlu untuk mempertimbangkan EPS dan DER dengan melihat naik turun besaran rasionya. Secara praktis bahwa dalam menentukan return saham investor jangan hanya memperhatikan faktor-faktor internal perusahan, akan tetapi harus memperhatikan faktor-faktor eksternal perusahaan.

Kata kunci: Faktor Fundamental, ROA, ROE, EPS, NPM, DER, CR, Return Saham.

\section{A. PENDAHULUAN}

Analisis fundamental merupakan suatu teknik analisis saham yang didasarkan pada kinerja perusahaan dengan menggunakan datadata yang berasal dari laporan keuangan perusahaan. Data tersebut diolah untuk menilai apakah suatu perusahaan memiliki kinerja dan kesehatan perusahaan yang baik. ${ }^{1}$ Venkatesh dan Tyagi menemukan bahwa analisis fundamental merupakan suatu metode perbandingan saham yang dipadukan dengan analisis teknikal. ${ }^{2}$ Suresh juga meneliti lingkungan ekonomi, kinerja industri dan kinerja keuangan sebelum membuat keputusan investasi. Hasil penelitiannya ditemukan bahwa analisis fundamental merupakan alat untuk penilaian sebelum

1 Budiman, R. Investing is Easy, Teknik Analisa dan Strategi Investasi Saham untuk Pemula. (Jakarta: Elex Media Komputindo, 2017), hlm. 20.

2 Venkatesh, C.K. dan Tyagi, M. Fundamental Analysis As A Method Of Share Valuation Comparison With Technical Analysis. Bangladesh Research Publication Journal, vol. 5, No. 3 (2011), hlm. 167-174. 
memutuskan investasi saham. ${ }^{3}$ Sementara Kumar et.al. menemukan bahwa analisis fundamental merupakan suatu alat strategi dalam memprediksi perilaku investasi perusahaan di masa mendatang. ${ }^{4}$ Sedangkan Voloshyna menyatakan bahwa fundamental merupakan kombinasi terbaik dalam memprediksi perilaku investasi pasar dalam meningkatkan return saham. ${ }^{5}$

Ada enam variabel independen dari analisis fundamental yang mempengaruhi Return Saham dalam penelitian ini, yaitu Return on Asset (ROA), Return On Equity (ROE), Net Profit Margin (NPM), Earnings per Share (EPS), Debt to Equity Ratio (DER), dan Current Ratio (CR).

ROA akan memperlihatkan berapa besar keuntungan yang akan didapat dari aset yang dimiliki perusahaan (Filbert dan Prasetya, 2017). ${ }^{6}$ ROA menggambarkan perputaran aktiva diukur dari volume penjualan, semakin besar rasio ini semakin baik. ${ }^{7}$ Hasil penelitian Rianto mengambarkan bahwa ROA memiliki pengaruh yang positif dan signifikan terhadap pengembalian saham. ${ }^{8}$

ROE digunakan untuk mengukur laba bersih sesudah pajak dengan modal sendiri. Rasio ini menunjukkan efesiensi penggunaan modal sendiri. Semakin tinggi rasio ini, semakin baik. Artinya posisi

3 Suresh, A.S,. A Study on Fundamental and Technical Analysis. International Journal of Marketing, Financial Services and Management Research, Vol. 2, No. 5, (2013), hlm. 2277-3622.

${ }^{4}$ Kumar, S., dan Warne, D. Parametric Determinants of Price Earning Ratio in Indian Capital Markets. The IUO Journal of Applied Finance, vol. 15 No. 9, (2014), hlm. 6382.

5 Voloshyna, K. Fundamental Analysis Vs Technical Analysis in The Egyptian Stock Exchange-Empirical Study. International Journal of Business and Management StudyIJBMS, vol. 2, No. 2, (2015), hlm. 212- 218.

${ }^{6}$ Filbert, R dan Prasetya, W. Investasi Saham ala Fundamentalis Dunia. (Jakarta: Elex Media Komputindo, 2017), hlm. 115.

${ }^{7}$ Harahap, S.S. Analisis Kritis atas Laporan Keuangan. (Jakarta: Rajawali Pers, 2015), hlm. 305 .

8 Rianto, M.R. Implikasi Return On Equity, Return On Asset, Net Income \& Debt To Equity Ratio Terhadap Return Saham Pada Perusahaan Properti. Jurnal Riset Manajemen dan Bisnis (JRMB) Fakultas Ekonomi UNIAT Vol.3, No.1, (2018), hlm. 59 - 66. 
pemilik perusahaan semakin kuat, demikian pula sebaliknya. ${ }^{9}$ Hasil penelitian Yustini menemukan bahwa ROE memiliki pengaruh positif terhadap return saham. ${ }^{10}$

EPS digunakan untuk mengukur keberhasilan manajemen dalam mencapai keuntungan bagi pemegang saham. EPS adalah indikator yang baik dari profitabilitas perusahaan sehingga banyak digunakan oleh para pengguna laporan keuangan. Hasil penelitian Sodikin dan Wuldani menemukan bahwa EPS berpengaruh psoitif terhadap return saham. ${ }^{11}$

Untuk mengukur margin laba atas penjualan digunakan NPM. Profit margin merupakan angka yang menunjukkan berapa besar persentase pendapatan bersih yang diperoleh dari setiap penjualan. Hasil Penelitian Aryanti dkk menemukan bahwa NPM berpengaruh terhadap return saham. ${ }^{12}$

DER digunakan untuk menilai utang terhadap ekuitas, sehingga untuk mengetahui keuntungan perusahaan terhadap ekuitas suatu perusahaan dapat menggunakan DER. Total Debt to Equity Ratio (rasio utang tehadap ekuitas) merupakan perbandingan antara hutanghutang dan ekuitas dalam pendanaan perusahaan dan menunjukkan kemampuan modal sendiri, perusahaan untuk memenuhi seluruh kewajibannya. ${ }^{13}$ Beberapa bukti empiris tentang efek terhadap pengembalian saham dalam penelitian yang dilakukan oleh Lestari dan Dewi menunjukkan pengaruh signifikan positif terhadap pengembalian saham yang diharapkan.

${ }^{9}$ Kasmir. Analisis Laporan Keuangan. (Jakarta: Rajawali Pers, 2016), hlm. 204.

10 Yustini, S,. Yusar, S,. dan Anis, S. The Effect Of Profitability, Value, Size and Managerial Discretion On Disclourse Of Stock Return. Jurnal Ilmu Akuntansi, vol. 11, No. 1, (2018), hlm. 169-182.

${ }^{11}$ Sodikin, S \& Wuldani, N. Pengaruh Price Earning Ratio (Per) dan Earning per Share (Eps) Terhadap Return Saham (Studi Pada Pt. Unilever Indonesia Tbk.) Jurnal Ekonomi Manajemen Universitas Siliwangi, vol 2. No. 1, (2016), hlm. 18-25.

12 Aryanti, Mawardi dan Andesta, S. Pengaruh ROA, ROE, NPM dan CR Terhadap Return Saham Pada Perusahaan Yang Terdaftar di Jakarta Islamic Index (JII). Journal IFinance, vol. 2, No. 2, (2016), hlm. 54-71.

${ }^{13}$ Sujarweni, V.W. Analisis Laporan Keuangan, Teori, Aplikasi, dan Hasil Penelitian. Yogyakarta: Pustaka Baru Press, 2017), hlm. 61. 
Current Ratio (CR) digunakan untuk mengukur kemampuan perusahaan dalam memenuhi kewajiban jangka pendek atau tagihan yang sudah kena tempo. ${ }^{14}$ Febriawan dan Santosa menemukan bahwa current ratio pengaruh positif terhadap return saham. ${ }^{15}$

Hasil yang tidak konsisten berdasarkan gap research tersebut masih perlu dilakukan penelitian lebih lanjut untuk menguji kembali apakah beberapa faktor fundamental memiliki pengaruh terhadap return saham. Penelitian ini dilakukan pada perusahaan sektor keuangan syariah yang terdaftar dalam Daftar Efek Syariah (DES). Pemilihan kelompok saham sektor keuangan syariah ini dikarenakan industri keuangan syariah di Indonesia sedang berkembang pesat akhir-akhir ini. Indonesia termasuk negara sepuluh besar dengan indeks keuangan syariah terbesar (Grafik 1) pada pasar global, sementara pertumbuhan keuangan syariah masih belum bisa mengimbangi pertumbuhan keuangan non syariah.

Berdasarkan Grafik 1 menunjukkan bahwa pangsa pasar keuangan syariah secara keseluruhan berada dibawah $5 \%$.

${ }^{14}$ Lestari, W.D. dan Dewi, R. Pengaruh ROA, DER, PBV dan PER terhadap Return Saham (Studi pada Perusahaan yang tercantum dalam LQ-45 di BEI tahun 2014-2016). (Posiding, Universitas Muhamadiyah, Surakarta), (2018). Hlm. 28.35.

${ }_{15}$ Febriawan, M dan Santosa, PW. Return Saham dan Faktor Fundamental Pada Pra Krisis Ekonomi Global 2008 di Bursa Efek Indonesia. Journal of Economics and Business Aseanomics (JEBA) Universitas YARSI, vol. 2 No.2, (2017), hlm. 232-248. 


\section{Grafik 1. Negara yang memiliki Aset Keuangan Syariah Terbesar16}

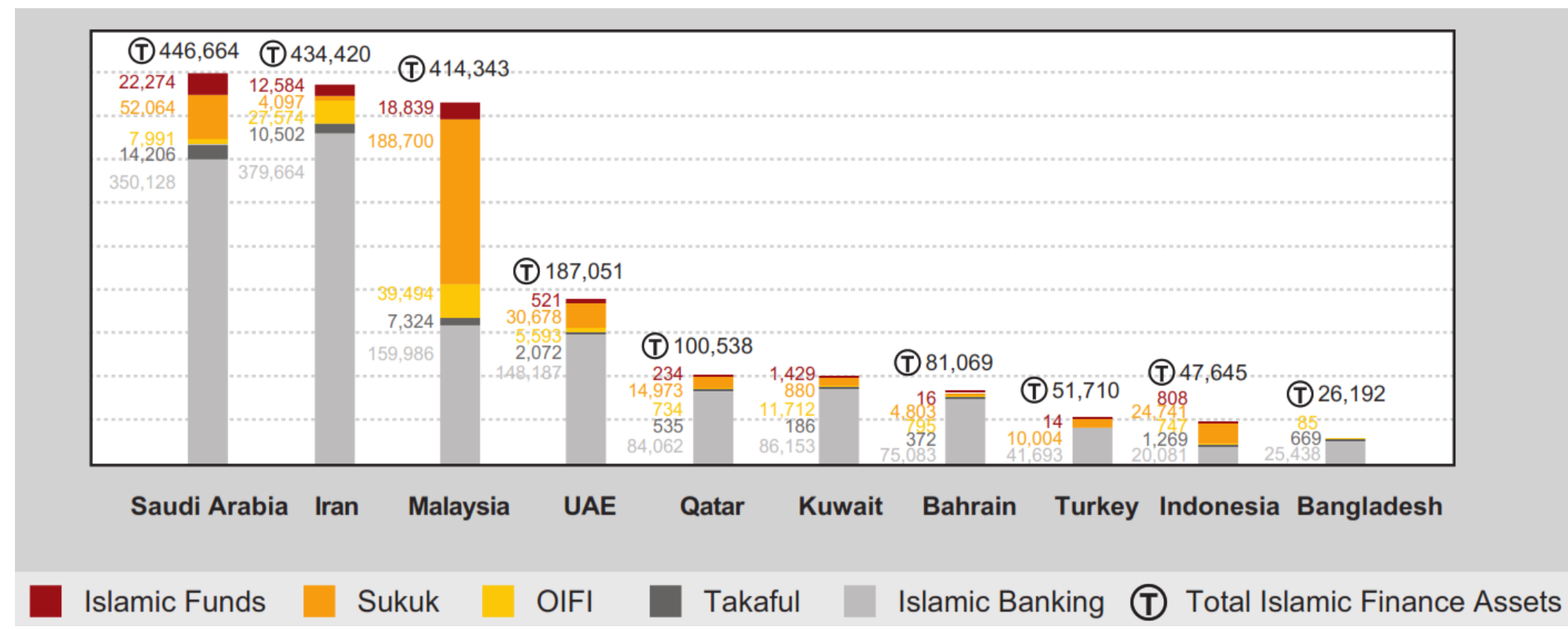

16 Otoritas Jasa Keuangan. Roadmap Pengembangan Keuangan Syariah Indonesia 2017-2019.https://www.ojk.go.id/id/kanal/syariah/berita-dankegiatan/publikasi/Documents/Pages/Roadmap-Pengembangan-Keuangan-Syariah-Indonesia-2017-2019/Roadmap\%202017-2019(1).pdf, diakses pada 30 September 2020. 
Sedangkan perkembangan total aset keuangan syariah Indonesia dapat terlihat pada Grafik landscape keuangan syariah Indonesia berikut:

Grafik 2. Landscape Keuangan Syariah Indonesia ${ }^{17}$

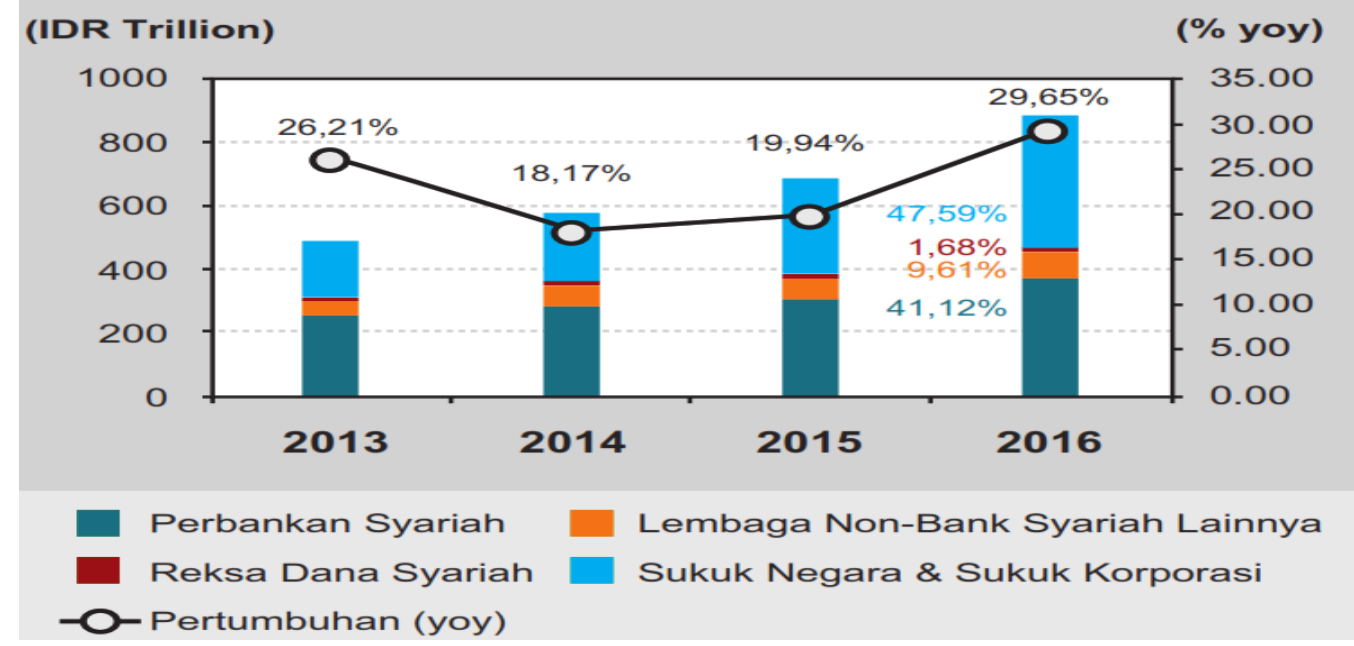

Berdasarkan tahun 2013 sampai dengan tahun 2016, Grafik 1 diatas menunjukkan bahwa total aset keuangan syariah Indonesia meningkat. Hanya pada tahun 2014 pertumbuhannya mengalami penurunan. Sedangkan pertumbuhan saham sektor keuangan syariah di Indonesia belum dapat mengimbangi pertumbuhan beberapa saham syariah lainnya. Hal ini dapat dlihat pada Grafik 3 berikut:

Grafik 3. Saham Syariah Berdasarkan Sektor ${ }^{18}$

\footnotetext{
17 Ibid

18 Otoritas Jasa Keuangan. Keputusan Dewan Komisioner Otoritas Jasa Keuangan Nomor Kep-24/D.04/2018 tentang Daftar Efek Syariah (DES). https://www.ojk.go.id/id/kanal/syariah/data-dan-statistik/daftar-efeksyariah/Documents/Pages/Keputusan-Dewan-Komisioner-OJK-Nomor-KEP-24-D.04-2018tentang-Daftar-Efek-Syariah/DES\%202018-p1.\%20Kep\%2024\%202018\%20240518.pdf, diakses pada 30 September 2020.
} 

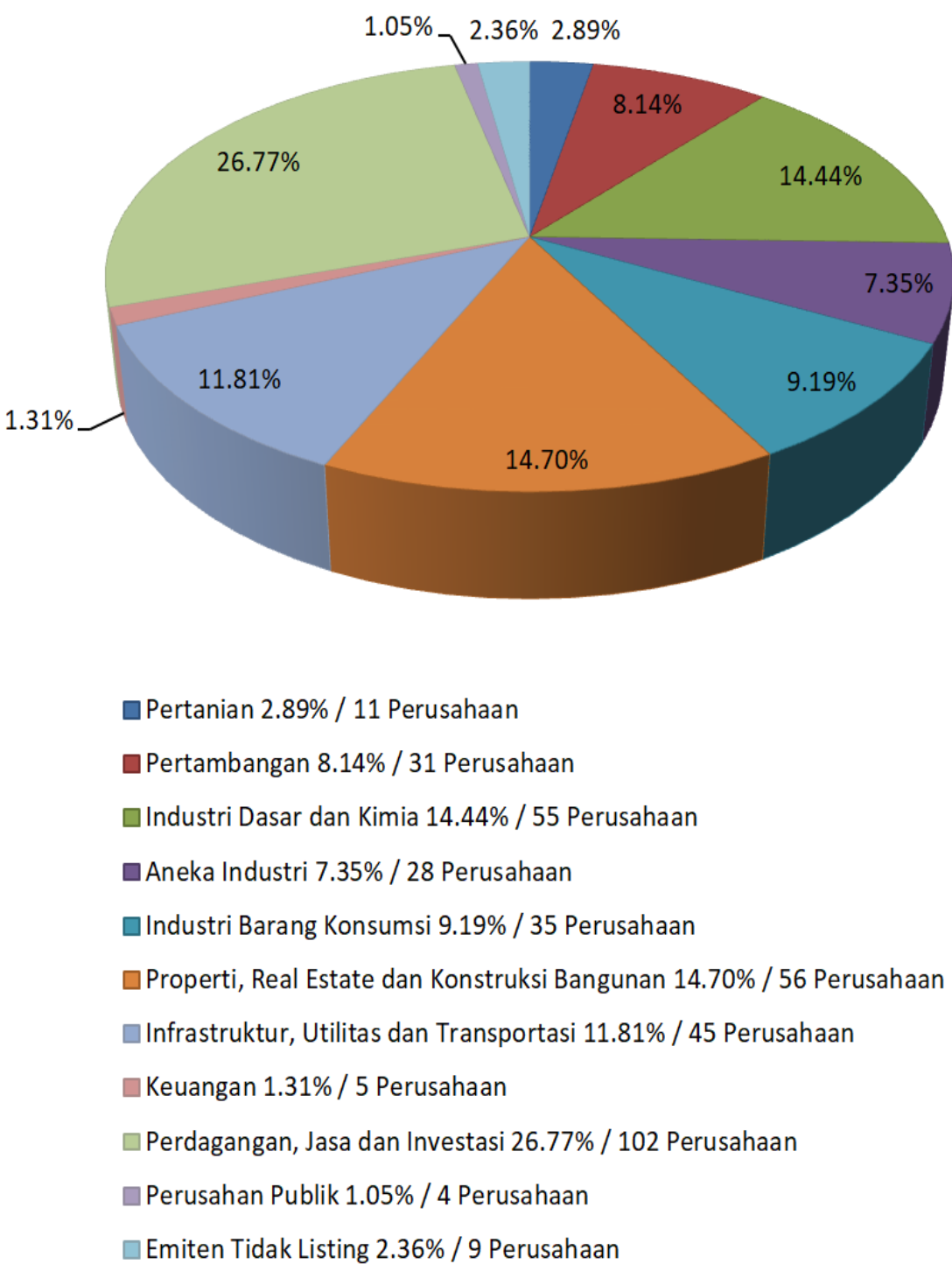

Berdasarkan Grafik 3 ditemukan bahwa jumlah perusahaan saham syariah Indonesia yang terdaftar dalam Daftar Efek Syariah adalah 381 perusahaan. Sementara, jumlah perusahaan sektor keuangan syariah Indonesia berada di posisi urutan kedua terakhir yaitu hanya 1,31\% atau 5 perusahaan dari total 381 jumlah perusahaan syariah yang terdiri dari:

Tabel 1.1. Jumlah Saham Syariah dalam

Daftar Efek Syariah Tahun 2018

\begin{tabular}{|c|l|c|}
\hline No & \multicolumn{1}{|c|}{ Sektor } & Jumlah perusahaan \\
\hline 1 & Pertanian & 11 \\
\hline
\end{tabular}




\begin{tabular}{|c|c|c|}
\hline 2 & Pertambangan & 31 \\
\hline 3 & Industri Dasar dan Kimia & 55 \\
\hline 4 & Aneka Industri & 28 \\
\hline 5 & $\begin{array}{l}\text { Properti, Real Estate dan Konstruksi } \\
\text { Bangunan }\end{array}$ & 35 \\
\hline 6 & Industri Barang Konsumsi & 56 \\
\hline 7 & Infrastruktur, Utilitas dan Transportasi & 45 \\
\hline 8 & Keuangan & 5 \\
\hline 9 & Perdagangan, Jasa dan Investasi & 102 \\
\hline 10 & Perusahaan Publik & 4 \\
\hline 11 & Emiten Tidak Listing & 9 \\
\hline & Total & 381 \\
\hline
\end{tabular}

Dari angka di atas perusahaan sektor keuangan syariah Indonesia perlu untuk terus dikembangkan sehingga dapat mengimbangi pertumbuhan saham sektor syariah yang lain.

Pertumbuhan jumlah saham sektor keuangan syariah yang terdaftar dalam DES (Daftar Efek Syariah) tergantung hasil penelahaan oleh OJK (Otoritas Jasa Keuangan) per periodik pada bulan Mei dan bulan November setiap tahunnya, serta penelaahan DES insidentil. Perusahaan dikatakan syariah jika utang berbunga milik emiten dan perusahaan publik adalah maksimal 45\% dari total asset; pendapatan tidak halal perusahaan maksimal 10\% dari total pendapatan perusahaan. ${ }^{19}$

Indonesia memiliki potensi pengembangan saham syariah yang sangat besar. Hal ini dikarenakan mayoritas penduduk Indonesia adalah muslim. Saham-saham yang terdaftar di DES merupakan rujukan bagi

19 Otoritas Jasa Keuangan. Pengantar Daftar Efek Syariah, https:// www.ojk.go.id/id/kanal/syariah/data-dan-statistik/daftar-efeksyariah/default.aspx, diakses 30 September 2020. 
masyarakat untuk memilih investasi saham syariah. Adanya DES ini, masyarakat mudah untuk mengetahui saham yang termasuk saham syariah. Aturan tentang Penerapan Prinsip Syariah dalam Mekanime Perdagangan Efek Bersifat Ekuitas di Pasar Reguler Bursa Efek telah diterbitkan oleh DSN-MUI (Dewan Syariah Nasional-Majelis Ulama Indonesia) dengan Fatwa No. 80 tahun 2011. Fatwa DSN-MUI tersebut akan menambah keyakinan investor dan masyarakat bahwa investasi syariah di pasar modal Indonesia sesuai dengan prinsip syariah.

Saham syariah juga dituntut untuk memperbaiki kinerja perusahaannya, karena return yang akan di prediksi oleh investor salah satunya adalah berasal dari faktor internal perusahaan itu sendiri yaitu faktor fundamental atau rasio keuangan dalam laporan keuangan sebuah perusahaan. Kinerja dan kesehatan perusahaan yang baik akan meningkatkan kepercayaan masyarakat untuk berinvestasi.

Objek penelitian kelompok saham yang bukan syariah sudah banyak dilakukan oleh peneliti sebelumnya, sementara penelitian yang menganalisis kinerja saham syariah khususnya sektor keuangan syariah relatif masih sangat sedikit. Perbedaan penelitian ini dengan penelitianpenelitian sebelumnya terletak pada periode penelitian, objek dan variabel penelitian yang berbeda. Beberapa hasil penelitian terdahulu menunjukkan hasil yang tidak konsisten sehingga perlu menguji kembali pengaruh beberapa faktor fundamental seperti ROA, ROE, EPS, NPM, DER dan CR terhadap return saham.

Metode analisis data yang digunakan dalam penelitian ini adalah analisis regresi linier berganda dengan pengujian kuantitatif untuk menguji hipotesis. Penentuan sampel penelitian menggunakan metode non probality sampling dengan pendekatan sampling jenuh dimana anggota populasi dijadikan sampel. Sampel dalam penelitian ini adalah seluruh perusahaan sektor keuangan syariah yang terdaftar dalam Daftar Efek Syariah dengan 
periode 2015-2017, yaitu:

a. PT. Bank Tabungan Pensiunan Nasional Syariah Tbk (BTPS)

b. PT. BRI Syariah Tbk (BRIS)

c. PT. Asuransi Jiwa Syariah Jasa Mitra Abadi Tbk (JMAS)

d. PT. Bank Panin Syariah Tbk (PNBS)

e. PT. Artavest (ARTA)

\section{B. HASIL PENGOLAHAN DATA}

\section{Analisis Regresi Linier Berganda}

Untuk menguji pengaruh beberapa variabel independen terhadap variabel dependen menggunakan ukuran rasio pada persamaan linier menggunakan analisis regresi linier berganda.

Tabel 1 Hasil Analisis Regresi Linear Berganda

\begin{tabular}{|c|c|c|c|c|c|}
\hline \multirow[t]{2}{*}{ Model } & \multicolumn{2}{|c|}{$\begin{array}{c}\text { Unstandardized } \\
\text { Coefficients }\end{array}$} & \multirow{2}{*}{\begin{tabular}{|c|}
$\begin{array}{c}\text { Standardized } \\
\text { Coefficients }\end{array}$ \\
Beta \\
\end{tabular}} & \multirow[t]{2}{*}{$\mathrm{t}$} & \multirow[t]{2}{*}{ Sig. } \\
\hline & $\mathrm{B}$ & Std. Error & & & \\
\hline (Constant) & 1,642 & 1,890 & & 0,869 & 0,410 \\
\hline ROA (X1) & $-9,672$ & 10,184 & $-0,412$ &,- 950 & 0,370 \\
\hline Ln ROE (X2) & 0,293 & 0,353 & 0,563 & 0,830 & 0,430 \\
\hline EPS (X3) & 0,198 & 0,150 & 0,828 & 5,554 & 0,016 \\
\hline Ln NPM (X4) & $-0,216$ & 0,339 & $-0,361$ & $-0,636$ & 0,543 \\
\hline DER (X5) & $-0,579$ & 0,007 & $-0,037$ & $-5,093$ & 0,031 \\
\hline Ln CR (X6) & 0,193 & 0,258 & 0,426 & 0,748 & 0,476 \\
\hline
\end{tabular}

Berdasarkan persamaan tersebut maka dapat dijelaskan sebagai berikut.

1. Konstanta sebesar 1,642 mengartikan bahwa jika variabel ROA, ROE, EPS, NPM DER dan CR konstan atau nol (X1, X2, X3, X4, X5 dan X6 =0) maka return saham sebesar 1,642 yang bersifat positif.

2. $\operatorname{ROA}\left(\mathrm{X}_{1}\right)$ terhadap return saham $(\mathrm{Y})$

Koefisien regresi ROA sebesar $-9,672$ berarti hubungan antara ROA terhadap return saham berlawanan. Apabila ROA naik maka return 
saham turun begitu juga sebaliknya dengan asumsi $x 1, x 2, x 3, x 4, x 5=$ 0

3. $\operatorname{ROE}\left(\mathrm{X}_{2}\right)$ terhadap return saham $(\mathrm{Y})$

Koefisien regresi ROE sebesar 0,293 berarti hubungan antara ROE terhadap return saham searah. Apabila ROE naik maka return saham juga akan naik begitu juga sebaliknya $x 1, x 2, x 3, x 4, x 5=0$

4. EPS $\left(\mathrm{X}_{3}\right)$ terhadap return saham $(\mathrm{Y})$

Koefisien regresi EPS sebesar 0,198 berarti hubungan antara EPS dengan return saham searah. Jika EPS naik maka return saham akan juga akan naik begitu sebaliknya $x 1, x 2, x 3, x 4, x 5=0$

5. $\mathrm{NPM}\left(\mathrm{X}_{4}\right)$ terhadap return saham $(\mathrm{Y})$

Koefisien regresi NPM sebesar $-0,216$ berarti hubungan antara NPM terhadap return saham tidak searah. Apabila NPM naik maka return saham akan turun begitu juga sebaliknya $x 1, x 2, x 3, x 4, x 5=0$

6. DER $\left(\mathrm{X}_{5}\right)$ terhadap return saham $(\mathrm{Y})$

Koefisien regresi DER sebesar $-0,579$ berarti hubungan antara DER terhadap return saham tidak searah. Apabila DER naik maka return saham akan turun begitu juga sebaliknya $x 1, x 2, x 3, x 4, x 5=0$

7. $\mathrm{CR}\left(\mathrm{X}_{6}\right)$ terhadap return saham $(\mathrm{Y})$

Koefisien regresi CR sebesar 0,193 berarti hubungan antara CR terhadap return saham searah. Apabila CR naik maka return saham juga akan naik begitu juga sebaliknya $x 1, x 2, x 3, x 4, x 5=0$

\section{Uji Koefesien Determinasi $\left(\mathbf{R}^{2}\right)$}

Hasil uji koefisien determinasi pada tabel 2 menunjukkan proporsi sumbangan pengaruh secara simultan dari ROA, ROE, EPS, NPM, DER dan CR terhadap return saham sebesar 33\% sedangkan sisanya sebesar $67 \%$ dipengaruhi variabel di luar penelitian. 
Tabel 2 Hasil Uji Koefesien Determinasi

\begin{tabular}{|l|r|r|r|r|r|}
\hline \multicolumn{7}{|c|}{ Model Summary } \\
\hline Model & $\mathrm{R}$ & R Square & $\begin{array}{c}\text { Adjusted R } \\
\text { Square }\end{array}$ & $\begin{array}{l}\text { Std. Error of } \\
\text { the Estimate }\end{array}$ & $\begin{array}{c}\text { Durbin- } \\
\text { Watson }\end{array}$ \\
\hline 1 &, $579 \mathrm{a}$ &, 330 &, 323 & 1,01879 & 1,568 \\
& & & & & \\
& & & & & \\
\hline
\end{tabular}

\section{Uji F}

Tabel 3 Hasil Uji F

\begin{tabular}{|c|c|c|c|c|c|c|}
\hline \multicolumn{7}{|c|}{$\mathrm{ANOVA}^{\mathrm{b}}$} \\
\hline \multicolumn{2}{|c|}{ Model } & $\begin{array}{l}\text { Sum of } \\
\text { Squares }\end{array}$ & $\mathrm{df}$ & $\begin{array}{l}\text { Mean } \\
\text { Square }\end{array}$ & $\mathrm{F}$ & Sig. \\
\hline \multirow[t]{3}{*}{1} & Regression & 4,191 & 6 & ,698 & 5,673 &, $047^{a}$ \\
\hline & Residual & 8,303 & 8 & 1,038 & & \\
\hline & Total & 12,494 & 14 & & & \\
\hline
\end{tabular}

a. Predictors: (Constant), Ln CR (X6), EPS (X3), Ln NPM (X4), ROA (X1), Ln ROE (X2), DER (X5)

b. Dependent Variable: Ln Return Saham (Y)

Berdasarkan hasil pengujian menunjukkan bahwa pengaruh yang diberikan oleh variabel ROA, ROE, EPS, NPM, DER dan CR terhadap Return Saham secara simultan terbukti positif dan signifikan. Hipotesis bahwa variabel ROA, ROE, EPS, NPM DER dan CR berpengaruh positif dan siginifikan terhadap return saham diterima. Hal ini ditunjukkan dari hasil uji F bahwa nilai siginifikansi < 0,05 (5\%).

\section{Uji t}


Tabel 4 Hasil uji $\mathrm{t}$

\begin{tabular}{|c|c|c|c|c|c|c|c|c|}
\hline \multicolumn{9}{|c|}{ Coefficients $^{\mathrm{a}}$} \\
\hline \multirow{3}{*}{\multicolumn{2}{|c|}{ Model }} & \multirow{2}{*}{\multicolumn{2}{|c|}{$\begin{array}{c}\text { Unstandardized } \\
\text { Coefficients }\end{array}$}} & \multirow{3}{*}{ 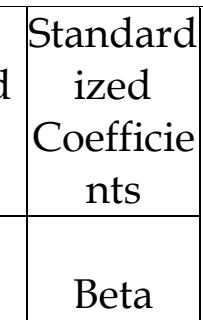 } & \multirow[b]{3}{*}{$\mathrm{t}$} & \multirow[b]{3}{*}{ Sig. } & \multirow{2}{*}{\multicolumn{2}{|c|}{$\begin{array}{c}\text { Collinearity } \\
\text { Statistics }\end{array}$}} \\
\hline & & & & & & & & \\
\hline & & \multirow{2}{*}{$\frac{B}{1,642}$} & \multirow{2}{*}{\begin{tabular}{|c|}
$\begin{array}{c}\text { Std. } \\
\text { Error }\end{array}$ \\
1,890
\end{tabular}} & & & & \multirow{2}{*}{\begin{tabular}{|l|} 
Toler \\
ance
\end{tabular}} & \multirow[t]{2}{*}{ VIF } \\
\hline 1 & (Constant) & & & & 869 & 410 & & \\
\hline & ROA (X1) &,- 672 & 10,184 &,- 412 &,- 950 & 370 & ,442 & 2,262 \\
\hline & Ln ROE (X2) & ,293 & ,353 &, 563 &, 830 & 430 & ,181 & 5,534 \\
\hline & EPS (X3) & ,198 & ,150 & 828 & 5,554 & ,016 & 292 & 3,420 \\
\hline & $\begin{array}{l}\text { Ln NPM } \\
(\mathrm{X} 4)\end{array}$ &,- 216 & ,339 &,- 361 &,- 636 &, 543 & ,257 & 3,885 \\
\hline & DER (X5) &,- 579 & ,007 &,- 037 & $-5,093$ & ,031 & ,092 & 1,841 \\
\hline & Ln CR (X6) & ,193 & ,258 & ,426 & ,748 & ,476 & ,257 & 3,895 \\
\hline
\end{tabular}

a. Pengaruh ROA terhadap Return Saham

Tingkat signifikansi variabel $\mathrm{ROA}$ adalah $0,370>$ dari $\alpha=0,05$. Setiap peningkatan atau penurunan variabel ROA tidak memiliki pengaruh terhadap peningkatan dan penurunan return saham pada perusahaan sektor keuangan syariah yang terdaftar dalam Daftar Efek Syariah tahun 2015-2017.

Hasil pengujian menunjukkan bahwa ROA tidak berpengaruh signifikan terhadap return saham. Hal ini menunjukkan bahwa hipotesis pertama yang menyatakan bahwa ROA berpengaruh positif dan signifikan terhadap return saham, ditolak.

ROA tidak berpengaruh siginifikan terhadap return saham. Hasil ini bertentangan dengan teori bahwa Return on Assets (ROA) menggambarkan sejauh mana kemampuan asset-aset yang dimiliki perusahaan dapat menghasilkan laba. Semakin besar rasio ini semakin baik. Adanya peningkatan pengembalian aset menunjukkan seberapa 
baik aset dikelola oleh perusahaan untuk mendatangkan keuntungan bagi setiap satu dolar aset yang telah diinvestasikan ke perusahaan. ${ }^{20}$

ROA yang tidak berpengaruh terhadap return saham dapat disebabkan oleh variabel ROA perusahaan yang tidak stabil pada periode penelitian 2015-2017. Variabel ROA tidak berpengaruh terhadap return saham. Hal itu menunjukkan bahwa kenaikan atau penurunan ROA tidak mampu berpengaruh terhadap kenaikan dan penurunan return saham. Hal itu dikarenakan ROA hanya bisa mengukur efektivitas perusahaan didalam menggunakan dari keseluruhan operasi perusahaan.

ROA yang tidak berpengaruh terhadap return saham disebabkan oleh investor selain memperhatikan kondisi internal perusahaan, mereka juga melihat risiko eksternal (inflasi, perubahan kebijakan ekonomi pemerintah, kenaikan tarif, dpresiasi yang lebih tinggi, kenaikan beban pokok penjualan, dan kondisi politik suatu negara). Faktor lain yang dilihat investor adalah kondisi pasar (permintaan dan penawaran pada pasar modal) yang berakibat pada fluktuasi harga yang memiliki pengaruh terhadap kepuasan investasi yang pada akhirnya mempengauri return saham. Artinya, berdasarkan hasil penelitian ini perubahan variabel ROA tidak serta merta berpengaruh terhadap tinggi rendahnya return saham, hal ini kemungkinan disebabkan perusahaan belum maksimal melakukan pengelolaan aset untuk memperoleh laba perusahaan. Hasil ini tidak sesuai dengan penelitian Rianto menunjukkan bahwa ROA berpengaruh positif dan signifikan terhadap pengembalian saham.

b. Pengaruh ROE perusahaan terhadap Return Saham ROE dengan nilai tingkat signifikansi sebesar $0,430>a=0,05$.

20 Aryono, Y., Isworo. dan Ediningsih, S. Pengaruh Right Issue terhadap Kinerja Keuangan pada Perusahaan yang Terdaftar di Bursa Efek Indonesia", Call For Paper Hasil-hasil Penelitian Dosen dan Seminar Nasional, (2009), hlm. 311-328. 
Perubahan variabel ROE meningkat atau menurunnya tidak mempengaruhi return saham sektor keuangan syariah yang terdaftar dalam Daftar Efek Syariah tahun 2015-2017.

Hasil pengujian menunjukkan bahwa ROE tidak berpengaruh signifkan terhadap return saham. Hipotesis kedua yang menyatakan bahwa ROE berpengaruh positif dan signifikan terhadap return saham, ditolak. Hal itu menunjukkan bahwa semakin tinggi ROE tidak menentukan return saham. Hasil tersebut bertentangan dengan teori bahwa semakin besar ROA semakin tinggi tingkat pengembalian return.

Variabel ROE tidak berpengaruh secara signifikan terhadap return saham menandakan bahwa perusahaan tidak dapat menjamin ekuitasnya dengan laba. Perusahaan yang masih berukuran kecil memiliki nilai ROE yang cenderung meningkat dengan cepat sejalan dengan peningkatan laba bersih (earning). Hal itu menyebabkan regresi linier dengan sampel perusahaan yang mempunyai fase pertumbuhan yang berbeda memberikan hasil yang tidak signifikan.

ROE tidak berpengaruh terhadap return saham. Hal itu menunjukkan bahwa modal sendiri yang ada diperusahaan meskipun dikelola menghasilkan laba tetapi tidak dapat memenuhi kebutuhan modal perusahaan. Hal tersebut menyebabkan laba yang diperoleh tidak mampu meningkatkan harga saham sehingga return saham tidak naik. Hasil ini bertentangan sesuai dengan teori bahwa Return On Equity merupakan tolak ukur profitabilitas, dimana para pemegang saham pada umumnya ingin mengetahui tingkat probabilitas modal saham dan keuntungan yang telah mereka tanam kembali dalam bentuk laba yang ditanam. Apabila saham perusahaan diperdagangkan di bursa saham, tinggi rendahnya Return On Equity akan mempengaruhi tingkat permintaan saham tersebut di bursa dan 
harga jualnya. Hasil penelitian ini tidak mendukung penelitian Yustini yang menemukan bahwa ROE berpengaruh positif terhadap return saham.

c. Pengaruh EPS Perusahaan terhadap Return Saham

EPS dengan nilai tingkat signifikansi sebesar 0,016 $<a=0,05$. Perubahan variabel EPS meningkat atau menurunnya berpengaruh terhadap return saham pada perusahaan sektor keuangan syariah yang terdaftar dalam Daftar Efek Syariah tahun 2015-2017.

Hasil pengujian menunjukkan bahwa EPS berpengaruh signifkan terhadap return saham. Hal ini menunjukkan bahwa hipotesis ketiga yang menyatakan bahwa EPS berpengaruh positif dan siginifikan terhadap return saham, diterima. Earning per Share (EPS) merupakan rasio yang menunjukkan berapa besar kemampuan per lembar saham menghasilkan laba. Keberhasilan manajemen mencapai keuntungan bagi pemegang saham diukur menggunakan Earning per Share (EPS)

Variabel EPS berpengaruh terhadap return saham disebabkan karena pada perusahaan sampel dalam periode penelitian 2015-2017 stabil. Berdasarkan hasil tersebut bahwa kinerja perusahaan sektor keuangan syariah produktif dalam memperoleh aktiva dan laba per lembar saham. Biaya operasional perusahaan ditekan dengan baik oleh manejemen sehingga mampu menghasilkan keuntungan yang maksimal.

Penelitian ini sesuai dengan teori bahwa EPS yang besar maka kemampuan peusahaan dalam meningkatkan keuntungan juga meningkat sehingga return yang diterima para pemegang saham juga meningkat. Penelitian Sodikin dan Wuldani juga menemukan bahwa EPS berpengaruh psoitif terhadap return saham. Dengan demikian, 
semakin tinggi nilai EPS, kesejahteraan pemegang saham meningkat karena tingkat pengembalian yang tinggi.

d. Pengaruh NPM Perusahaan terhadap Return Saham

NPM dengan nilai tingkat signifikansi sebesar 0,543> a $=0,05$. Perubahan variabel NPM meningkat atau menurunnya tidak berpengaruh terhadap return saham pada perusahaan sektor keuangan syariah yang terdaftar dalam Daftar Efek Syariah tahun 2015-2017.

Hasil pengujian menunjukkan bahwa NPM tidak berpengaruh signifkan terhadap return saham. Hal ini menunjukkan bahwa hipotesis empat yang menyatakan bahwa NPM berpengaruh positif dan signifikan terhadap return saham, ditolak. Hasil ini bertentangan dengan teori bahwa semakin tinggi nilai NPM suatu perusahaan maka semakin tinggi return saham.

Hal tersebut bisa disebabkan oleh kinerja perusahaan yang kurang menghasilkan pendapatan tertentu atau penekanan biaya operasional yang kurang maksimal oleh perusahaan yang pada akhirnya keuntungan bersih yang dihasilkan tidak maksimal. Variabel NPM tidak berpengaruh terhadap return saham juga disebabkan oleh nilai variabel NPM yang tidak stabil pada periode penelitian 2015-2017 juga mempengaruhi return saham perusahaan. Minat investor untuk berinvestasi pada perusahaan tersbut juga akan menurun. Artinya return saham juga akan menurun.

Hasil ini mengindikasikan bahwa besarnya NPM yang dihasilkan oleh perusahaan tidak berpengaruh signifikan terhadap return saham. Kondisi ini kontradiktif dengan teori yang mendasarinya bahwa NPM menunjukkan tingkat kembalian keuntungan bersih terhadap penjualan bersihnya dan sekaligus menunjukkan efisiensi biaya yang dikeluarkan perusahaan. Sehingga 
jika NPM semakin besar atau mendekati satu, maka berarti semakin efisien biaya yang dikeluarkan sehingga semakin besar besar tingkat kembalian keuntungan bersih, semakin meningkatnya NPM, maka daya tarik investor semakin meningkat sehingga harga saham juga akan meningkat. Hasil ini tidak konsisten dengan penelitian Aryanti dkk menemukan bahwa NPM berpengaruh terhadap return saham.

e. Pengaruh DER Perusahaan Perusahaan terhadap Return Saham DER memiliki tingkat signifikansi sebesar 0,031<a =0,05. perubahan variabel NPM meningkat atau menurunnya berpengaruh terhadap return saham pada perusahaan sektor keuangan syariah yang terdaftar dalam Daftar Efek Syariah tahun 2015-2017.

Hasil pengujian menunjukkan bahwa DER berpengaruh positif dan signifkan terhadap return saham. Hal ini menunjukkan bahwa hipotesis lima yang menyatakan bahwa DER berpengaruh positif dan signifikan terhadap return saham, diterima. Hasil ini sejalan dengan teori bahwa DER digunakan untuk mengetahui berapa besar untung yang dimiliki perusahaan bila dibandingkan dengan ekuitasnya. DER yang tinggi mencerminkan risiko solvabilitas perusahaan yang relatif tinggi dan sebagai akibatnya, investor cenderung menghindari perusahaan dengan hutang tinggi atau perusahaan yang memiliki DER tinggi. Hal itu menunjukkan bahwa DER yang tinggi justru menurunkan return saham.

Hasil ini mengindikasikan adanya pertimbangan yang berbeda dari beberapa investor dalam memandang DER. Oleh sebagian investor DER dipandang besarnya tanggung jawab perusahaan terhadap pihak ketiga yaitu kreditur yang memberikan pinjaman kepada perusahaan. Sehingga semakin besar nilai DER akan memperbesar tanggungan perusahaan. Namun demikian nampaknya beberapa investor justru memandang bahwa perusahaan yang 
tumbuh pasti akan memerlukan hutang sebagai dana tambahan untuk memenuhi pendanaan pada perusahaan yang tumbuh. Perusahaan tersebut memerlukan banyak dana operasional yang tidak mungkin dapat dipenuhi hanya dari modal sendiri yang dimiliki perusahaan. Kondisi ini menyebabkan kemungkinan berkembangnya perusahaan dimasa yang akan datang yang berujung pada meningkatnya return saham.

Kondisi ini mengandung arti bahwa ketergantungan perusahaan dengan pihak eksternal semakin kecil sehingga tinggkat resiko perusahaan semakin kecil yang ditunjukkan dengan rendahnya DER. Sebaliknya DER yang tinggi menunjukkan utang perusahaan yang tinggi sehingga beban besar berdampak pada kinerja perusahaan yang kurang baik dan mengurangi keuntungan perusahaan. Perusahaan yang mimiliki tingkat utang yang tinggi dan dibebankan ke pemegang saham akan meningkatkan resiko kepada para investor selaku pemegang saham, tentu akan mengurangi minat mereka untuk berinvestasi. Hasil penelitian ini konsisten dengan Penelitian Lestari dan Dewi juga menunjukkan DER berpengaruh signifikan terhadap return saham.

f. Pengaruh CR Perusahaan Perusahaan terhadap Return Saham

CR memiliki tingkat signifikan sebesar 0,476 > a =0,05. Perubahan variabel CR meningkat atau menurunnya tidak berpengaruh terhadap return saham pada perusahaan sektor keuangan syariah yang terdaftar dalam Daftar Efek Syariah tahun 2015-2017.

Berdasarkan hasil pengujian menunjukkan bahwa pengaruh CR terhadap return saham adalah tidak signifikan. Hal ini menunjukkan bahwa hipotesis enam yang menyatakan bahwa CR berpengaruh positif dan signifikan terhadap Return Saham, ditolak. Kondisi ini mengandung arti bahwa CR yang rendah biasanya 
dianggap menunjukkan terjadinya masalah dalam likuiditas dan merupakan indikator awal mengenai ketidakmampuan perusahaan untuk memenuhi kewajiban jangka pendeknya.

Kondisi ini mengandung arti bahwa CR yang rendah biasanya dianggap menunjukkan terjadinya masalah dalam likuiditas dan merupakan indikator awal mengenai ketidakmampuan perusahaan untuk memenuhi kewajiban jangka pendeknya. CR yang tinggi, yang berarti likuiditas yang tinggi juga menunjukkan bahwa perusahaan kurang mampu mengelola money to create money, yang pada akhirnya dapat mengurangi laba perusahaan.

Investor sering menilai bahwa semakin besar $C R$ menunjukkan besarnya kemampuan perusahaan dalam memenuhi kebutuhan operasionalnya terutama modal kerja yang sangat penting untuk menjaga perfomance kinerja perusahaan yang pada akhirnya mempengaruhi performance harga saham. Hal ini dapat memberikan keyakinan kepada investor untuk memiliki saham perusahaan tersebut sehingga dapat meningkatkan return saham.

Hasil ini tidak sesuai dengan teori yang menyatakan bahwa CR yang tinggi, yang berarti likuiditas yang tinggi juga menunjukkan bahwa perusahaan mampu mengelola money to create money, yang pada akhirnya dapat meningkatkan kemampuan perusahaan untuk melunasi kewajiban jangka pendeknya. Hasil penelitian ini tidak konsisten dengan Febriawan dan Santosa yang menyatakan bahwa current ratio berpengaruh signifkan terhadap return saham.

\section{KESIMPULAN}

ROA, ROE, EPS, NPM, DER dan CR secara simultan berpengaruh positif dan signifikan terhadap return saham. Secara parsial hanya variabel EPS dan DER yang berpengaruh positif dan sifnifikan terhadap return saham. Pengaruh ROA, ROE, EPS, NPM, DER dan CR terhadap return 
saham sebesar 33\% sedangkan sisanya sebesar 67\% dipengaruhi variabel di luar penelitian. DER lebih dominan berpengaruh terhadap return saham dibandingkan dengan EPS.

Berdasarkan penelitian ini, investor dan calon investor perlu mempertimbangkan EPS dan DER dengan melihat perubahan besaran rasionya, selain faktor internal perusahaan, faktor eksternal perusahaan juga harus menjadi perhatian. Bagi perusahaan hendaknya memberi perhatian lebih terhadap segala aspek keuangan perusahaan, meningkatkan EPS dan menurunkan DER atau hutang dengan mencari sumber dana lain yang kecil risiko bagi perusahaan.

Peneliti selanjutnya dapat melakukan perbandingan pengaruh dari dua sektor atau lebih misalkan sektor manufaktur, jasa dan lain-lain sehingga akan mendapatkan hasil komparasi dua sektor atau lebih. 


\section{DAFTAR PUSTAKA}

Aryono, Y., Isworo. dan Ediningsih, S. (2009). Pengaruh Right Issue terhadap Kinerja Keuangan pada Perusahaan yang Terdaftar di Bursa Efek Indonesia", Call For Paper Hasil-hasil Penelitian Dosen dan Seminar Nasional.

Aryanti, Mawardi dan Andesta, S. (2016). Pengaruh ROA, ROE, NPM dan CR Terhadap Return Saham Pada Perusahaan Yang Terdaftar di Jakarta Islamic Index (JII). Journal I-Finance, vol. 2, No. 2.

Budiman, R. (2017). Investing is Easy, Teknik Analisa dan Strategi Investasi Saham untuk Pemula. Jakarta: Elex Media Komputindo.

Febriawan, M dan Santosa, PW. (2017). Return Saham dan Faktor Fundamental Pada Pra Krisis Ekonomi Global 2008 di Bursa Efek Indonesia. Journal of Economics and Business Aseanomics (JEBA) Universitas YARSI, vol. 2 No.2.

Filbert, R dan Prasetya, W. (2017). Investasi Saham ala Fundamentalis Dunia. Jakarta: Elex Media Komputindo.

Harahap, S.S. (2015). Analisis Kritis atas Laporan Keuangan. Jakarta: Rajawali Pers.

Kasmir. (2016). Analisis Laporan Keuangan. Jakarta: Rajawali Pers.

Kumar, S., dan Warne, D. (2014). Parametric Determinants of Price Earning Ratio in Indian Capital Markets. The IUO Journal of Applied Finance, vol. 15 No. 9.

Lestari, W.D. dan Dewi, R. (2018). Pengaruh ROA, DER, PBV dan PER terhadap Return Saham (Studi pada Perusahaan yang tercantum dalam LQ-45 di BEI tahun 2014-2016). Posiding, Universitas Muhamadiyah, Surakarta.

Otoritas Jasa Keuangan. Keputusan Dewan Komisioner tentang Daftar Efek Syariah (DES). https://www.ojk.go.id/id/kanal/syariah/data-danstatistik/daftar-efek-syariah/Documents/Pages/Keputusan-DewanKomisioner-OJK-Nomor-KEP-24-D.04-2018-tentang-Daftar-EfekSyariah/DES\%202018-p1.\%20Kep\%2024\%202018\%20240518.pdf, diakses pada 30 September 2020.

. Roadmap Pengembangan Keuangan Syariah Indonesia 20172019.https://www.ojk.go.id/id/kanal/syariah/berita-dan- 
kegiatan/publikasi/Documents/Pages/Roadmap-PengembanganKeuangan-Syariah-Indonesia-2017-2019/Roadmap\%202017-2019(1).pdf, diakses pada 30 September 2020.

Pengantar Daftar Efek Syariah. https://www.ojk.go.id/id/kanal/syariah/data-dan-statistik/daftarefek-syariah/default.aspx, diakses 30 September 2020.

Rianto, M.R. (2018). Implikasi Return On Equity, Return On Asset, Net Income \& Debt To Equity Ratio Terhadap Return Saham Pada Perusahaan Properti. Jurnal Riset Manajemen dan Bisnis (JRMB) Fakultas Ekonomi UNIAT Vol.3, No.1.

Sodikin, S \& Wuldani, N (2016). Pengaruh Price Earning Ratio (Per) dan Earning per Share (Eps) Terhadap Return Saham (Studi Pada Pt. Unilever Indonesia Tbk.) Jurnal Ekonomi Manajemen Universitas Siliwangi, vol 2. No. 1.

Suresh, A.S,. (2013). A Study on Fundamental and Technical Analysis. International Journal of Marketing, Financial Services and Management Research, Vol. 2, No. 5.

Venkatesh, C.K. dan Tyagi, M. (2011). Fundamental Analysis As A Method Of Share Valuation Comparison With Technical Analysis. Bangladesh Research Publication Journal, vol. 5, No. 3.

Voloshyna, K. (2015). Fundamental Analysis Vs Technical Analysis in The Egyptian Stock Exchange-Empirical Study. International Journal of Business and Management Study-IJBMS, vol. 2, No. 2.

Yustini, S,. Yusar, S,. dan Anis, S. (2018). The Effect Of Profitability, Value, Size and Managerial Discretion On Disclourse Of Stock Return. Jurnal Ilmu Akuntansi, vol. 11, No. 1. 